\title{
Application of accrual accounting in Iran municipalities
}

\author{
Ali Eamaeilzade Maghariee ${ }^{\mathrm{a}}$, Zahra Houshmand Neghabi ${ }^{\mathrm{b} *}$ and Rahele Abdic
}

${ }^{a}$ Assist. Prof. \& Faculty Member, Department of Accounting, School of Accounting and Management, Islamshahr Branch, Islamic Azad University (IAU), Iran

${ }^{b}$ Faculty Member, Department of Commercial Management, School of Management and Accounting, Islamshahr Branch, Islamic Azad University (IAU), Iran

${ }^{c}$ M.Sc. Student, Department of Accounting, School of Management and Accounting, Islamshahr Branch, Islamic Azad University (IAU), Iran

\section{H R O N I C L E}

\begin{tabular}{l}
\hline Article history: \\
Received October 28, 2014 \\
Received in revised format 15 \\
January 2015 \\
Accepted 27 January 2015 \\
Available online \\
January 282015 \\
\hline Keywords: \\
Accrual accounting \\
Municipality \\
Cash accounting
\end{tabular}

\section{Introduction}

Accrual accounting is a technique for recognizing expenses when incurred and revenue when earned rather than when payment is made or received (Christiaens \& Rommel, 2008; He et al., 2008). In the cash method of accounting, on the other hand, cash receipts and disbursements technique of accounting or cash accounting records revenue when cash is earned, and expenses when they are paid in cash. There are different advantages on using accrual accounting such as incremental of information (Bowen et al., 1987; Badertscher et al., 2012; Salleh et al., 2014) and many firms have recently joined to use such accounting system (Guthrie, 1998). There have been also an increasing numbers of debates

*Corresponding author. Tel: +98-912-3434650

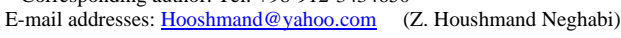

(c) 2015 Growing Science Ltd. All rights reserved. doi: 10.5267/j.msl.2015.1.013 
between adoptions of cash accounting versus accrual accounting in government accounting. Azmi and Mohamed (2014) performed an empirical investigation to determine the readiness of Malaysian public sector employees in the Ministry of Education (MOE) to use accrual accounting, major concerns together with challenges in moving towards accrual accounting.

According to Hyndman and Connolly (2011), the move from cash to accruals accounting by many governments is considered as a perspective of an ongoing New Public Management agenda designed to reach a more business-like and performance-focused public sector. Proponents argue that accruals accounting gives more suitable information for decision makers and eventually leads to a more effective public sector. The move from cash to accruals accounting for UK central government agencies was announced in the early 1990s and was accomplished within approximately ten years. Gårseth-Nesbakk (2011) presented a case study of an accrual accounting change attempt at central government level in Norway. They explained how the debits represent something new and interrelations with other accounting environments. Becker et al. (2013) discussed the translation of accrual accounting and budgeting and the integration of public sector accountants' information. Hepworth (2003) presented a

comprehensive survey on preconditions for successful implementation of accrual accounting in central government.

Falkman and Tagesson (2008) described that the regulation of Swedish municipal accounting had undergone some significant changes where a standard-setting body was adopted, with responsibility for development and interpretation of accepted accounting regulations for municipal accounting. The objectives of the legislation and reform were to push 'creative' accounting and to increase the level of comparability. Their results described that the reform had had a very limited impact on accounting practice and it was not fairly compliance with existing accounting standards. Kwon (1989) studied that that accrual accounting was superior to cash-basis accounting in terms of expenses. The main reason was described that accrual accounting information could more fully reflect the overall effects of managerial actions or endeavors on future cash flows than cash flow realizations in any given period. Therefore, accrual accounting information is more efficient than traditional accounting information for both motivating managers to expend efforts and sharing risks under moral hazard.

\section{The proposed method}

We present an empirical investigation to study the effect of implementing accrual accounting in municipality of Amol, Iran. The proposed study of this paper considers the following two hypotheses,

1. Financial reporting based on accrual accounting compared with a cash basis provides a better method for promoting accountability.

2. Converting cash to accrual accounting basis in municipalities improves qualitative characteristics of accounting information.

To examine the first hypothesis of the survey, regression technique has been used and to test the second hypothesis, we have designed a questionnaire in Likert scale to measure the quality characteristics of the accounting information. The proposed study has been accomplished among regular employees who worked either as accounting or in management team of this organization. The sample size is calculated as follows,

$$
n=\frac{N \times z_{\alpha / 2}^{2} \times p \times q}{\varepsilon^{2} \times(N-1)+z_{\alpha / 2}^{2} \times p \times q},
$$


where $N$ is the population size, $p=1-q$ represents the yes/no categories, $z_{\alpha / 2}$ is CDF of normal distribution and finally $\varepsilon$ is the error term. Since we have $p=0.5, z_{\alpha / 2}=1.96$ and $N=100$, the number of sample size is calculated as $n=65$. There were 25 questions in the questionnaire and we first presented it to some expert to verify the quality of the questionary. Next, the questionnaire was distributed among some limited number of people where Cronbach alpha (Cronbach, 1951) was equal to 0.84, which was well above the minimum acceptable level. Therefore, we have distributed 80 questionnaires and managed to collect 69 properly filled ones.

\section{The results}

\subsection{The first hypothesis: Accountability of accrual versus cash}

The first hypothesis investigates whether or not financial reporting based on accrual accounting compared with a cash basis could provide a better method for promoting accountability. To examine this hypothesis, we first extracted all information of accrual and cash from the statements of the manicipality of Amol and then we used kolmogorov-Smirnov test to verify whether the data were normally distributed or not and the result has confirmed that the data were indeed normally distributed. Table 1 shows details of our survey on testing random effect versus fixed effect. In addition, Table 2 presents the results of Hausman test.

\section{Table 1}

The results of F-value and Chi-Square values associated with Limmer test

\begin{tabular}{cccc}
\hline & Base & df & Probability \\
\hline Cross-section F & 1.483 & $-45,228$ & 0.034 \\
Cross-section Chi-square & 70.84 & 45 & 0.008 \\
\hline
\end{tabular}

\section{Table 2}

The summary of Hausman test

\begin{tabular}{cccc}
\hline Description & Base & df & Probability \\
\hline Cross-section random & 2.4421 & 2 & 0.2949 \\
\hline
\end{tabular}

According to the results of Table 1 and Table 2, we use Panel data with random effect. Using, regression analysis, the study compares the performance of accrual accounting versus cash accounting and the results have indicated that accrual accounting could improve the performance of accounting in municipality system. Table 3 shows details of our findings.

Table 3

The results of regression analysis

\begin{tabular}{ccccc}
\hline Variable & Coefficient & Std. Error & t-Statistic & Prob. \\
\hline Intercept & 0.243813 & 0.124541 & 1.957684 & 0.0513 \\
Accrual accounting & 0.101665 & 0.005022 & 20.24392 & 0.0000 \\
\hline
\end{tabular}

\subsection{The second hypothesis: The effect of accrual accounting on quality of information}

The second part of this survey investigates whether accrual accounting could provide better quality information about accounting activities. To examine this hypothesis, the study has designed a questionnaire in Likert scale to measure the quality of information and the survey has concluded accrual accounting indeed provided better quality characteristics information. 


\section{Conclusion}

In this paper, we have performed an empirical investigation to study the effects of accrual accounting on providing better accounting management in municipality organization. The study has applied regression technique to find out the degree of responsiveness of accrual accounting against traditional system and a questionnaire has been used to learn the effect of accrual accounting on increasing the quality of information. The results of the survey have confirmed that accrual accounting could contribute on both the level of responsiveness as well as the quality of information. The results of this survey are consistent with earlier findings on the literature (Badertscher et al., 2012; Becker et al., 2013; Azmi \& Mohamed, 2014).

\section{Acknowledgement}

The authors would like to thank the anonymous referees for constructive comments on earlier version of this paper. We are also grateful for cooperation of employees of Amol municipality.

\section{References}

Azmi, A. H., \& Mohamed, N. (2014). Readiness of Malaysian public sector employees in moving towards accrual accounting for improve accountability: The case of ministry of education (MOE). Procedia-Social and Behavioral Sciences, 164, 106-111.

Badertscher, B. A., Collins, D. W., \& Lys, T. Z. (2012). Discretionary accounting choices and the predictive ability of accruals with respect to future cash flows. Journal of Accounting and Economics, 53(1), 330-352.

Becker, S. D., Jagalla, T., \& Skærbæk, P. (2013). The translation of accrual accounting and budgeting and the reconfiguration of public sector accountants' identities. Critical Perspectives on Accounting, 25(4-5), 324-338.

Bowen, R. M., Burgstahler, D., \& Daley, L. A. (1987). The incremental information content of accrual versus cash flows. Accounting Review, 62(4), 723-747.

Cronbach, L. J. (1951). Coefficient alpha and the internal structure of tests. Psychometrika, 16(3), 297334.

Christiaens, J., \& Rommel, J. (2008). Accrual accounting reforms: only for businesslike (parts of) governments. Financial Accountability \& Management, 24(1), 59-75.

Falkman, P., \& Tagesson, T. (2008). Accrual accounting does not necessarily mean accrual accounting: Factors that counteract compliance with accounting standards in Swedish municipal accounting. Scandinavian Journal of Management, 24(3), 271-283.

Gårseth-Nesbakk, L. (2011). Accrual accounting representations in the public sector-A case of autopoiesis. Critical Perspectives on Accounting, 22(3), 247-258.

Guthrie, J. (1998). Application of accrual accounting in the Australian public sector-rhetoric or reality. Financial Accountability \& Management, 14(1), 1-19.

He, H., El-Masry, E., \& Wu, Y. (2008). Accounting conservatism of cross-listing firms in the pre- and post-Sarbanes Oxley periods. Advances in Accounting, 24(2), 237-242

Hepworth, N. (2003). Preconditions for successful implementation of accrual accounting in central government. Public Money \& Management, 23(1), 37-44.

Hyndman, N., \& Connolly, C. (2011). Accruals accounting in the public sector: A road not always taken. Management Accounting Research, 22(1), 36-45.

Kwon, Y.K. (1989). Accrual versus cash-basis accounting methods: An agency-theoretic comparison. Journal of Accounting and Public Policy, 8(4), 267-281.

Salleh, K., Ab Aziz, R., \& Bakar, Y. N. A. (2014). Accrual accounting in government: Is fund accounting still relevant?. Procedia-Social and Behavioral Sciences, 164, 172-179. 